Redaktionlelle Verantw 1 rtung: FMH SERVICES

\title{
Geld und Aufwand
} sparen?

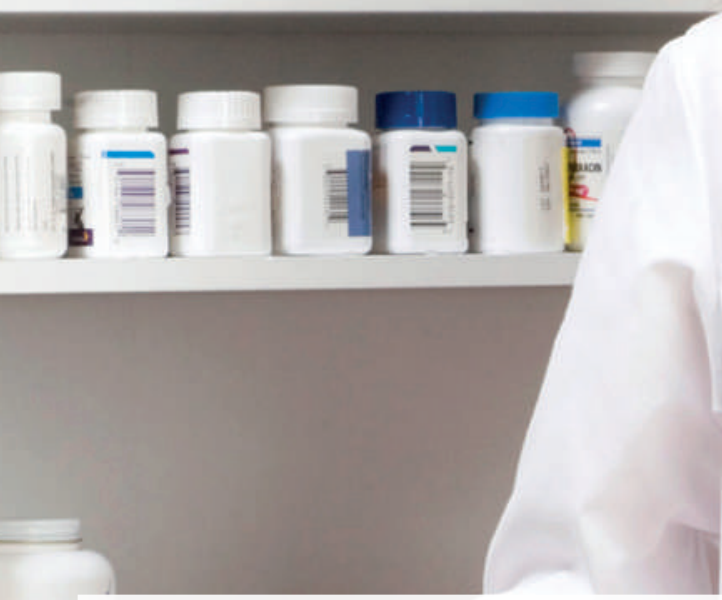

\section{(2) H. HII}
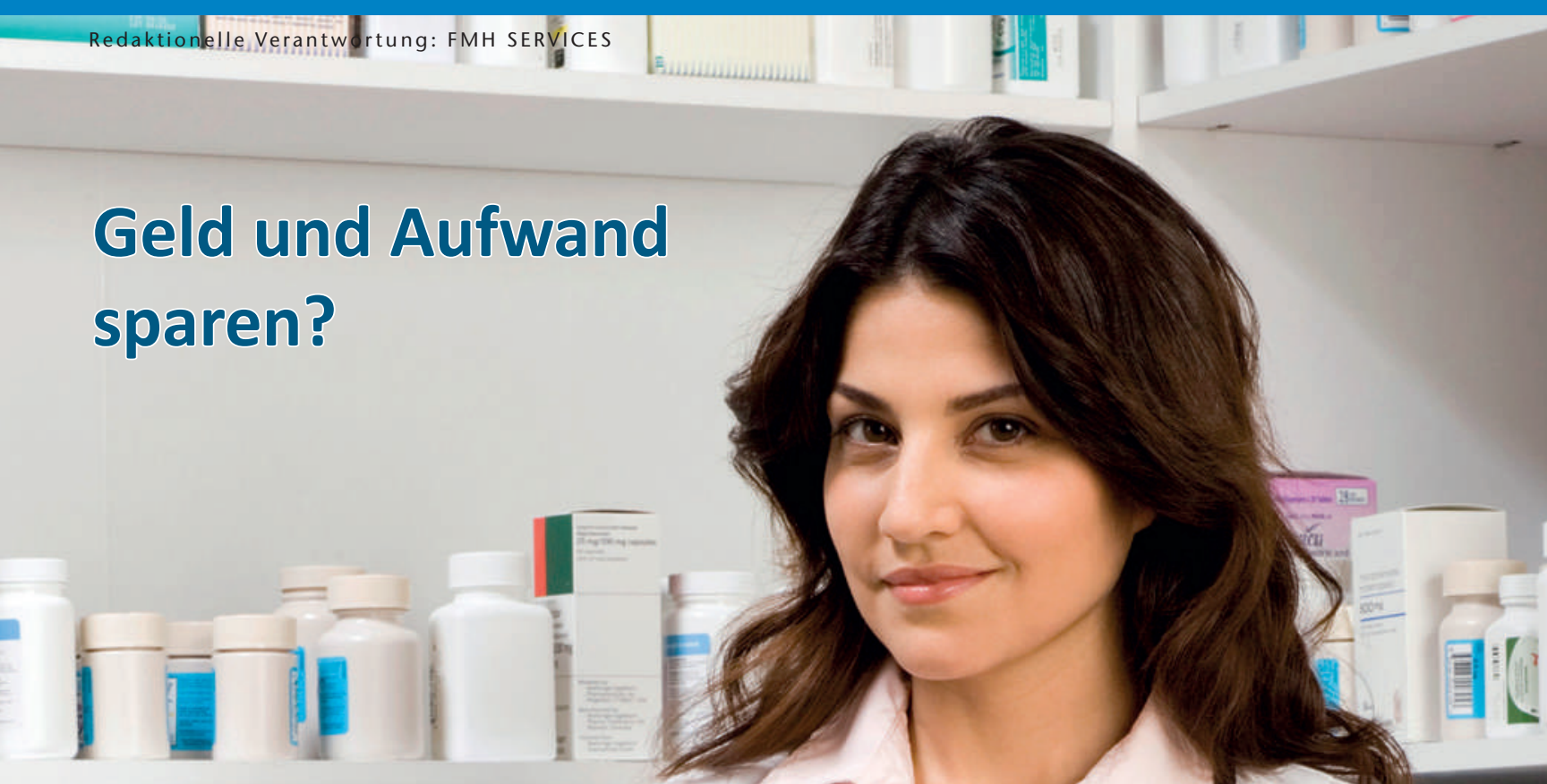

Sparen Sie Geld
medizintechni
Ihre Vorteile:

- Direktbestellung bei unserer grossen Auswahl von Vertragslieferanten (www.fmhservices.ch)

- Monatliche Sammelrechnung mit verlängerter Zahlungsfrist

- Für Neukunden im ersten Jahr bis zu 2\% Rabatt auf all Ihren Einkäufen

\section{GEMEINSAMER EINKAUF FÜR ÄRZTINNEN UND ÄRZTE}

Ich bin interessiert. Bitte kontaktieren Sie mich.

Vorname / Name

Adresse

PLZ / Ort

Geburtsdatum

Telefon Privat / Geschäft

Beste Zeit für einen Anruf

E-Mail-Adresse

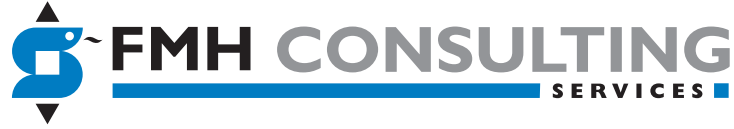

FMH Consulting Services AG

Burghöhe 1, 6208 Oberkirch

Tel. 0419250077 - Fax 0419210586

mail@fmhconsulting.ch - www.fmhservices.ch 